\title{
Sian sisäpaisteista valmistettujen kinkkuleikkeiden laatu
}

\author{
Marita Ruusunen, Liisa Voutila ja Eero Puolanne
}

HY/elintarviketeknologian laitos, Viikki EE, PL 66,00014 Helsinki, marita.ruusunen@helsinki.fi

\section{Tiivistelmä}

Sian sisäpaisteissa on todettu PSE-tyyppistä väri/rakennevirhettä. Virheellisten sisäpaistien väri on vaalea ja siinä voidaan lihassyykimput erottaa helposti toisistaan sormin repimällä. Laatuvirhe voi esiintyä joko vain pienellä alueella sisäpaistia syvällä luun vieressä, tai paisti voi olla kauttaaltaan virheellinen.

Kokeessa tutkittiin normaaleista (ryhmä 1) ja laatuvirheellisistä (ryhmä 2) sian sisäpaisteista valmistettujen kinkkuleikkeiden ominaisuuksia. Raaka-aineena käytettävät sisäpaistit luokiteltiin leikkaamossa ryhmään 1 (ei poikkeavaa väriä/rakennetta) ja ryhmään 2 (väri ja rakennemuutoksia koko lihaksessa). Sisäpaistien pH-arvo sekä vaaleus, punaisuus ja keltaisuus mitattiin leikkaamossa, josta paistit kuljetettiin tuotteiden valmistuspaikkaan. Sisäpaisteista mitattiin kuljetuksen ja varastoinnin aikainen valuma. Kinkkuleikkeiden valmistus aloitettiin n. 26 tunnin kuluttua näytteenotosta hienontamalla sisäpaistit $13 \mathrm{~mm}$ laipalla. Maseeraus kesti $1 \mathrm{~h} 15$ min, mutta laukan annettiin vaikuttaa ennen ruiskutusta ja kypsennystä 15 tuntia. Kypsistä kinkkuleikkeistä määritettiin kypsennyspainotappio, kuoren alle irronneen geelin määrä, $\mathrm{pH}$-arvo sekä aistinvaraisesti veden sitoutuminen, leikkauspinnan rakenne, värin tummuus ja punaisuus. Triangelitestillä selvitettiin, pystyvätkö arvioijat erottamaan ryhmien kinkkuleikkeet maun ja ulkonäön perusteella toisistaan.

Ryhmän 2 sisäpaistit olivat kauttaaltaan vaaleampia (suurempi L*arvo) kuin ryhmän 1 sisäpaistit. Kaikki mitatut pH-arvot olivat ryhmässä 2 alempia kuin ryhmässä 1.

Ryhmän 1 sisäpaisteissa oli valuma kuljetuksen ja säilytyksen (26 h) aikana 7 g/kg lihaa ja ryhmän 2 sisäpaisteissa 29 g/kg lihaa. Kypsennyspainotappio oli ryhmän 1 kinkkuleikkeissä 19 g/kg ja ryhmän 2 kinkkuleikkeissä 16 g/kg. Kypsien kinkkuleikkeiden kuoren alla ei ryhmässä 1 ollut juurikaan irronnutta geeliä (3 g/kg), mutta ryhmässä 2 irronnutta geeliä oli $22 \mathrm{~g} / \mathrm{kg}$.

Vaikka ryhmän 1 kinkkuleikkeissä oli aistinvaraisesti arvioituna hieman parempi vedensidonta ja leikkauspinnan rakenne kuin ryhmän 2 kinkkuleikkeissä sekä selvästi tummempi ja punaisempi väri kuin ryhmän 2 kinkkuleikkeissä, eivät arvioijat pystyneet erottamaan ryhmien kinkkuleikkeitä toisistaan triangelitestillä. Eräänä syynä pieniin aistinvaraisiin eroihin oli se, että lihat jauhettiin ennen maseerausta $13 \mathrm{~mm}$ laipalla. Tällöin kinkkuleikkeiden leikkauspinnalla ei ole näkyvissä suuria lihapaloja, joissa rakenne-erot näkyisivät helpommin.

Johtopäätöksenä voidaan todeta, että tutkimuksen kohteena olevaa PSE-tyyppistä väri/rakennevirhettä esiintyy eriasteisena melko runsaasti sisäpaisteissa. Tästä aiheutuu ongelmia valuman muodossa sekä mahdollisesti myös tuotteen ulkonäössä. Ilmiö on yhteydessä sisäpaistin pHarvoon. Jos sisäpaistin pH-arvo on korkea, ongelmaa ei juurikaan esiinny.

Asiasanat: sian sisäpaisti, valuma, kinkkuleike, kypsennyspainotappio, pH, väri 


\section{Johdanto}

Sisäpaisteissa esiintyy varsin usein värin vaaleutta sekä lihaksen ulkopinnalla että syvällä lihaksessa luun lähellä. Ilmiö on tuttu muuallakin, ja esimerkiksi Ranskassa (Franck ym., 2002), Irlannissa (O'Neill ym., 2003 Voutila ym., 2005), Sveitsissä (Hugenschmidt ym., 2007) ja USAssa on raportoitu samasta ongelmasta. Vaikuttaa kuitenkin siltä, että Suomessa esiintymistiheys on samaa luokkaa kuin edellä mainituissa maissa, esimerkiksi ranskalaisen tutkimuksen (Minvielle ym. 2001) mukaan siellä virhettä esiintyy n. 17 \%:issa ruhoista. Franck ym., (2002) arvioivat laatuvirheen esiintyvyydeksi 1020 \% Ranskassa. Laatuvirhe on vahvasti kytköksissä pH-arvoon siten, että loppu-pH-arvon ollessa alle 5,50 viallisia oli n. $60 \%$, kun taas sen ollessa yli 6,00 virhe oli vain $1 \%$ :issa ruhoja. Ilmiö on lähinnä PSE-tyyppinen: vaaleanruskea väri, valuma suuri ja rakenne irtoileva. HY/lihateknologian piirissä on erityisesti kiinnitetty huomiota lihaksen hajoavuuteen ja sidekudoksen mahdollisen heikkouden merkitykseen ilmiön synnyssä. Sen vuoksi tätä lihaa on tullut tavaksi kutsua "höttölihaksi".

Ilmiö sinänsä on tuttu, mutta juuri tästä materiaalista ei ole tehtynä lihavalmisteita. Tämän vuoksi kokeen tarkoituksena oli selvittää sisäpaistin sisäosan laatuvirheen esiintymistä, sisäpaistien valumaa sekä vertailla virheellisistä sisäpaisteista tehtyjen karkeastihienonnettujen lihavalmisteiden (kinkkuleike) ominaisuuksia vastaaviin normaaleista sisäpaisteista valmistettujen lihavalmisteiden ominaisuuksiin.

Aiemmin oli selvitetty ilmiön esiintymistiheyttä ja todettu laatuvirheen esiintymistiheydeksi eriasteisena 25-40 \%. Prosenttiluku ei tarkoita samaa kuin ko. lihan osuus koko lihamäärästä, vaan osuus on pienempi siksi, että tavallisimmin virheellistä lihaa on vain osa sisäpaistista. Hyvin ongelmallisia sisäpaisteja on huomattavasti vähemmän.

\section{Aineisto ja menetelmät}

Tutkimukseen haettiin näytteet teollisuudesta. Sisäpaistit luokiteltiin aluksi aistinvaraisesti sekä värin että rakenteen perusteella. Ryhmään 2 luokiteltujen sisäpaistien väri oli vaalea ja siinä voitiin lihassyykimput erottaa helposti toisistaan sormin repimällä. Ryhmään 1 valittiin sisäpaisteja, joissa ei todettu väri ja rakenneongelmaa. Molempiin ryhmiin valittiin 15 sisäpaistia. Sekä virheellisten ryhmästä että kontrolliryhmästä valittiin 15 sisäpaistia tarkempiin analyyseihin. Sisäpaistien väri ja pHarvo mitattiin leikkaamossa. Sisäpaistit kuljetettiin seuraavana päivänä Helsingin yliopiston lihateknologian koetehtaaseen, jossa niistä valmistettiin leiketyyppisiä lihavalmisteita. Aikaa näytteenotosta lihavalmisteiden valmistukseen kului 26 tuntia. Näytteet otettiin leikkaamossa, joten siat oli teurastettu vähintään vuorokausi aiemmin.

Sisäpaistien luokittelussa tutkittiin yhteensä 427 sisäpaistia, joista 295 kpl (69,1 \%) luokiteltiin ryhmään 1 . ja 15 kpl (3,5\%) ryhmään 2. Jälkimmäisen ryhmän sisäpaisteissa väri- ja rakennemuutoksia oli todettavissa koko lihaksessa. Muissa tutkituissa sisäpaisteissa todettiin eriasteisia väri- ja rakennemuutoksia.

Väri (L*, a*, b*) mitattin Minolta CR-200 mittarilla kolmesta eri sisäpaistin kohdasta (Taulukko 1). 1) pinta syvällä sisäpaistissa luun vieressä, jossa muutoksia useimmiten tavataan, 2) sisäpaistin keskiosasta, tämä osa on yleensä tummempi, 3) vaalea kohta sisäpaistin pinnalla, tämä kohta näkyy ruhon halkaisupinnalla. Väri mitattiin tuoreelta leikkauspinnalta. pH-arvot mitattiin Knick Portamess 752- mittarilla (elektrodi Mettler Toledo Inlab 427) samoista kohdista kuin värikin sekä lisäksi ruhon halkaisukohdassa näkyvästä sisäpaistin tummemmasta osasta (adductor-lihas). Kinkkuleikkeet tehtiin sisäpaistin semimembranosus- ja adductor-lihaksista.

Valuma määritettiin punnitsemalla irronneen nesteen määrä, joka valui lihoista näytteenoton ja laukan lisäämisen välillä (aika n. 26 tuntia). Valuma ilmoitetaan prosentteina. Ennen maseerausta lihat jauhettiin $13 \mathrm{~mm}$ laipalla. Kuljetuksen aikana valunut neste lisättiin takaisin lihojen joukkoon ennen maseerausta.

Kinkkuleikkeiden valmistuksessa käytettiin $8 \mathrm{~kg}$ lihaa, 1,4 kg vettä, 24 g natriumfosfaattiseosta, 7,7 g 10 prosenttista $\mathrm{NaNO}_{2}$-liuosta, 5,8 g natriumaskorbaattia ja 172,8 g suolaa (1,8 \%). Maseeraus- 
aika oli 1 h 15 min. Laukka sai kuitenkin vaikuttaa kaikissa 15 tuntia. Kypsennyspainotappio laskettiin punnitsemalla kinkkuleikkeet raakoina sekä kypsennyksen ja jäähdytyksen jälkeen, noin neljä tuntia kypsennyksen aloittamisesta. Lopuksi punnittiin kinkkuleikkeet kuorineen ja kuorittuina. Kuoren alla ollut irronnut geeli ilmoitettiin prosentteina (Taulukko 2).

Triangelitestillä testattiin pystyvätkö arvioijat erottamaan ryhmien 1 ja 2 kinkkuleikkeet maun ja ulkonäkön perusteella toisistaan. Arviointiin osallistui yhdeksän arvioijaa. Lisäksi arvioijat arvioivat kuvailevalla analyysillä kinkkuleikkeiden vedensidontaa $(0=$ heikko, $10=$ voimakas), leikkauspinnan rakennetta $(0=$ mureneva, $10=$ kiinteä $)$, värin voimakkuutta $(0=$ vaalea, $10=$ tumma $)$ ja värin punaisuutta ( $0=$ heikko, $10=$ voimakas). Näytteinä oli $5 \mathrm{~mm}: n$ paksuiset kinkkuleikeviipaleet. Samat yhdeksän arvioijaa kuin triangelitestissäkin arvioivat kinkkuleikeviipaleet (Taulukko 3).

Erot ominaisuuksissa ryhmien välillä testattiin tilastollisesti SAS ohjelmalla (SAS Institute Inc. (1999).

\section{Tulokset ja tulosten tarkastelu}

Ryhmän 2. sisäpaistit olivat vaaleampia ( $\mathrm{L}^{*}$-arvot) kuin ryhmän 1. sisäpaistit kaikissa kolmessa värin mittauskohdassa (Taulukko 1). Punaisuudessa ( $a^{*}$-arvo) ei ilmennyt samalaista tendessiä. Syvällä sisäpaistissa ryhmän 2. sisäpaistit olivat jopa punaisempia. Keltaisuutta kuvaavat arvot (b*- arvo) olivat ryhmän 2. sisäpaisteissa vähän suurempia. Väri mitattiin tuoreelta leikkauspinnalta. Yleensä leikkauspinnan pitäminen valossa vaikuttaa eniten $L^{*}$ - ja b*-arvoihin, siten että sekä vaaleus että keltaisuus lisääntyvät. pH-arvo oli ryhmän 2. sisäpaisteissa merkitsevästi alempi kuin ryhmän 1 . Syvällä sisäpaistissa ero oli 0,23 pH-yksikköä ja sisäpaistin pinnalla ruhon halkaisukohdassa 0,24 pHyksikköä. Sisäpaistin sisäosassa ero oli pienin 0,17 pH-yksikköä. Samansuuntainen ero ryhmien välillä todettiin värin vaaleudessa, ero oli pienin sisäpaistin sisäosassa.

Ryhmän 1. sisäpaisteista valui selvästi vähemmän lihasnestettä säilytyksen ja kuljetuksen aikana, 7 g/kg (Taulukko 2). Ryhmän 2. sisäpaisteissa valuma oli vastaavasti 29 g/kg. Tuotteiden valmistuksen aikana kypsennyspainotappiot olivat ryhmässä $1.19 \mathrm{~g} / \mathrm{kg}$ ja ryhmässä $2.16 \mathrm{~g} / \mathrm{kg}$. Ryhmän 1 . kinkkuleikkeissä oli kypsennyksen ja jäähdytyksen jälkeen kuoren alla $3 \mathrm{~g} / \mathrm{kg}$ irronnutta geeliä ja ryhmässä 2. $22 \mathrm{~g} / \mathrm{kg}$. Kokonaishävikki koko prosessin aikana, raaka-aineen valinta-kypsä tuote, oli ryhmässä $1.29 \mathrm{~g} / \mathrm{kg}$ ja ryhmässä $2.67 \mathrm{~g} / \mathrm{kg}$. Ero oli $38 \mathrm{~g} / \mathrm{kg}$.

Vaikka ryhmän 1. kinkkuleikkeissä oli aistinvaraisesti arvioituna vähän parempi vedensidonta ja leikkauspinnan rakenne kuin ryhmän 2. kinkkuleikkeissä sekä selvästi tummempi ja punaisempi väri kuin ryhmän 2. kinkkuleikkeissä (Taulukko 3), eivät arvioijat pystyneet erottamaan ryhmien kinkkuleikkeitä toisistaan triangelitestillä. Kuusi arvioijaa yhdeksästä pystyi erottamaan eroavan näytteen. Eräänä syynä pieniin aistinvaraisiin eroihin oli se, että lihat jauhettiin ennen maseerausta $13 \mathrm{~mm}$ laipalla. Tällöin kinkkuleikkeiden leikkauspinnalla ei ole näkyvissä suuria lihapaloja, joissa rakenne-erot näkyisivät helpommin

\section{Johtopäätös}

Johtopäätöksenä voidaan todeta, että tutkimuksen kohteena olevaa väri/rakennevirhettä esiintyy melko runsaasti sisäpaisteissa. Tästä aiheutuu ongelmia valuman muodossa sekä mahdollisesti myös kypsän tuotteen ulkonäössä. Ilmiö on yhteydessä sisäpaistin pH-arvoon. Jos sisäpaistin pH-arvo on korkea, ongelmaa ei juurikaan esiinny. 
Taulukko 3. Aistinvarainen arviointi kuvailevalla analyysillä; vedensidonta ( $0=$ heikko, $10=$ voimakas), leikkauspinnan rakenne $(0=$ mureneva, $10=$ kiinteä $)$, värin voimakkuus $(0=$ vaalea, $10=$ tumma $)$ ja värin punaisuus (0=heikko, 10=voimakas).

\begin{tabular}{lccc}
\hline & Kontrolli & Ryhmä 2 & P \\
\hline Vedensidonta & $6,2 \pm 2,2$ & $5,1 \pm 2,0$ & \\
Leikkauspinnan rakenne & $6,3 \pm 2,2$ & $5,7 \pm 2,2$ & $* * *$ \\
Värin voimakkuus & $6,6 \pm 1,2$ & $3,7 \pm 1,0$ & $* * *$ \\
Värin punaisuus & $6,7 \pm 1,4$ & $3,6 \pm 0,8$ & \\
\hline $\begin{array}{l}\text { Ryhmä 1 (raaka-aineena käytetyissä sisäpaisteissa ei poikkeavaa väriä/rakennetta); ryhmä 2 } \\
\text { (raaka-aineena käytetyissä sisäpaisteissa väri ja rakennemuutoksia koko lihaksessa). ***P<0,001. }\end{array}$
\end{tabular}

\section{Kirjallisuus}

Franck, M., Monin, G., Figwer, P., Poirel, M. T. \& Legault, C. 2002. Strukturloses Fleisch - ein ernsthaftes Problem. Problematik bei der industriellen Herstellung von Kochschinken. Fleischwirtsch. 12: 97-100.

Hugenschmidt, G., Hadorn, R., Suter, M., Scheeder, M. \& Wenk, C. 2007. Anteil und Schweregrad destrukturierter Zonen in Kochschinken. Fleischwirtsch. 87: 100-103.

Minvielle, B., Le Strat, P., Lebret, B., Houix, Y., Boulard, J. \& Clochefert, N. 2001. Viandes déstructurées. Situation dans cinq abattoirs de l'Ouest de la France:facteurs de risque et proposition d'un modèle. Caractérisation colorimétrique, biochimique et histologique. Journées Recherche Porcine en France 33: 95-101.

O'Neill, D. J., Lynch, P. B., Troy, D. J., Buckley, D. J. \& Kerry, J. P. 2003. Effects of PSE on the quality of cooked hams. Meat Sci. 64: 113-118.

Voutila, L., Mullen A. M., Allen, P., Troy, D., \& Puolanne, E. 2005. Thermal stability of connective tissue and meat quality of loose structured pork semimembranosus muscles. In Proceedings $51^{\text {st }}$ international congress of meat science and technology (pp. 228-232), 7-12 August 2005, Baltimore, USA. 